\title{
PENGARUH VARIASI MAIN JET NOZZEL PADA SISTEM KARBURATOR TERHADAP UNJUK KERJA MESIN (Studi Kasus Beberapa Tingkat Oktan)
}

\author{
Charlie Christian, Abrar Riza dan Harto Tanujaya \\ Program Studi Teknik Mesin Universitas Tarumanagara, Jakarta \\ e-mail: CharlieChristian22@yahoo.com
}

\begin{abstract}
This study discusses the effect of variations in the diameter of the main jet nozzle and three types of fuel with an octane rating of 88, 90 and 92 on the performance of the motor fuel. Performance analysis covering torque, power and specific fuel consumption (SFC). In order to determine the maximum performance that can be generated on any variation of the diameter of the main jet nozzles, and types of fuel. At the time of this experiment performed with a 4 stroke engine Honda GX-160, using hydro tool dynamometer and uses premium fuel. The data taken is the engine rotation, the force measured on the dynamometer and the time spent fuels. Tests conducted at the Laboratory of Energy Conversion Mechanical Engineering UNTAR Jakarta. Testing is done by means of rotational load mengvariasikan to gain strength in each round machine with a variety of major diameter nozzle jet fuel and octane. Variation of the engine rotation starts at minimal rotation until maximum.
\end{abstract}

Keywords: main jet nozzles, octane fuel, motor fuel performance, dynamometer

\section{PENDAHULUAN}

Pada saat ini motor bakar merupakan mesin yang sering dijumpai dan digunakan pada berbagai keperluan untuk membantu kebutuhan manusia seperti keperluan transportasi, pemakaian rumah tangga dan industri. Motor bakar adalah salah satu jenis dari mesin konversi energi yang mengubah energi termal untuk melakukan kerja mekanik atau mengubah tenaga kimia bahan bakar menjadi tenaga mekanis. Energi pada motor bakar diperoleh dari proses pembakaran bahan bakar dikonversikan menjadi energi mekanik, yang kemudian energi mekanik ini yang akan dimanfaatkan untuk proses tertentu.

Pada dasarnya energi dari motor bakar tidak bisa langsung dimanfaatkan jika tidak dihubungkan pada mesin. Dalam pemilihan suatu motor bakar haruslah disesuaikan dengan kebutuhan alat yang akan dihubungkan pada motor bakar tersebut. Jika yang dibutuhkan tenaga misalnya untuk ngangkut beban, tentulah torsi dari motor bakar yang dibutuhkan. Jika yang dibutuhkan kecepatan, maka daya dari motor bakar yang dibutuhkan. Oleh sebab itu, sebagai parameter pemilihan yaitu dengan cara mengetahui performa dari mesin motor bakar yang akan dipilih. Parameter tesebut dapat berupa torsi, daya, dan konsumsi bahan bakar dari motor bakar dan putaran mesin. Jika tidak memperhatikan aspek tersebut, maka pada pengoprasian motor bakar akan tidak efisien bahkan akan mengakibatkan kerusakan baik dari motor bakar tersebut ataupun mesin yang akan dihubungkan.

Pembakaran yang terjadi di dalam ruang motor bakar dipengaruhi oleh tiga faktor yaitu adanya oksigen, bahan bakar, dan panas (heat). Tanpa adanya ketiga faktor itu pembakaran tidak mungkin terjadi. Pada mesin otto, bahan bakar dimasukkan dengan dua cara ada yang menggunakan karburator dan ada yang menggunakan injeksi bahan bakar. Karburator digunakan untuk mencampur bahan bakar dengan udara. Jumlah bahan bakar yang masuk ini dipengaruhi oleh ukuran lubang (diameter) di dalam main jet nozzle. Semakin besar ukuran nosel nya maka akan semakin banyak bahan bakar yang masuk ke dalam karburator dan ini akan mempengaruhi proses pembakaran yang terjadi.

Kelebihan: Lebih hemat bahan bakar, tidak menggunakan oli samping sehingga lebih ekonomis, Tenaga yang dihasilkan besar dan stabil, sehingga memiliki akselerasi yang baik pada medan pegunungan atau jalan menanjak, Asap yang dihasilkan dari proses pembakaran (relative) tidak ada atau ramah lingkungan.

Banyak faktor yang mempengaruhi peforma motor bakar seperti posisi jarak celah elektroda busi, campuran bahan bakar dan masih ada cara lain yang mempengaruhi performa suatu motor 
bakar. Busi berfungsi untuk membakar campuran udara bensin yang telah dimampatkan dengan jalan memberi loncatan api listrik diantara kedua elektrodanya. Karena itu motor bensin dinamai dengan spark ignitions. Sedangkan karburator adalah tempat bercampurnya udara dan bensin. Campuran tersebut kemudian masuk ke dalam silinder yang dinyalakan oleh loncatan bunga api listrik dari busi menjelang akhir langkah kompresi. Salah satu cara faktor yang mempengaruhi peforma motor bakar selain yang telah disebutkan sebelumnya, yaitu nosel atau pilot jet. Fungsi nosel adalah pengabutan bahan bakar atau ada yang menyebut dengan Injektor. Disebut injektor karena tugas dari komponen ini adalah menginjeksi, dan disebut pengabut karena bahan bakar keluar dari komponen ini dalam bentuk kabut, sedangkan disebut nosel karena ujung komponen ini luas penampang semakin mengecil. Dari hal tersebut bisa dilihat pada kondisi nosel yang berbeda akan mengakibatkan perbedaan berapa persen motor bakar dapat mengeluarkan daya dan torsi maksimal serta dapat dilihat juga berapa nilai konsumsi bahan bakar pada setiap variasi nosel pada pengujian.

Berdasarkan latar belakang tersebut, maka penulis mengambil skripsi dengan judul: Pengaruh variasi main jet nozzle pada sistem karburator terhadap unjuk kerja mesin (Studi kasus beberapa tingkat oktan)

\section{Tujuan Penelitian}

Melihat efek pengabutan dan efek nilai oktan di ruang bakar terhadap unjuk kerja mesin. Dan mendapatkan karakteristik unjuk kerja mesin Akibat tekanan dan pengabutan tersebut.

\section{KAJIAN PUSTAKA}

Pada siklus ideal, diasumsikan fluida kerjanya hanya udara sebagai gas ideal yang kalor spesifiknya konstan. Pada proses langkah kerja seperti langkah hisap dan buang diasumsikan terjadi pada tekanan konstan. Untuk langkah kompresi dan tenaga dianggap pada keadaan adiabatik. Pada siklus ini kalor diperoleh dari sumber kalor dan tidak ada proses penyalaan (tidak ada reaksi 6 kimia). Siklus udara pada motor bakar yang sering dijumpai adalah siklus otto, siklus disel dan siklus gabungan.

Siklus otto ini sering disebut juga siklus dengan siklus ledakan, hal ini dikarenakan proses pembakaran terjadi sangat cepat sehingga menyebabkan peningkatan tekanan yang tiba-tiba. Pada siklus ini penyalaan pada proses pembakaran dibantu dengan loncata bunga api. Untuk lebih jelas proses yang terjadi pada siklus ini bisa dilihat pada diagram p-v di bawah ini [3].

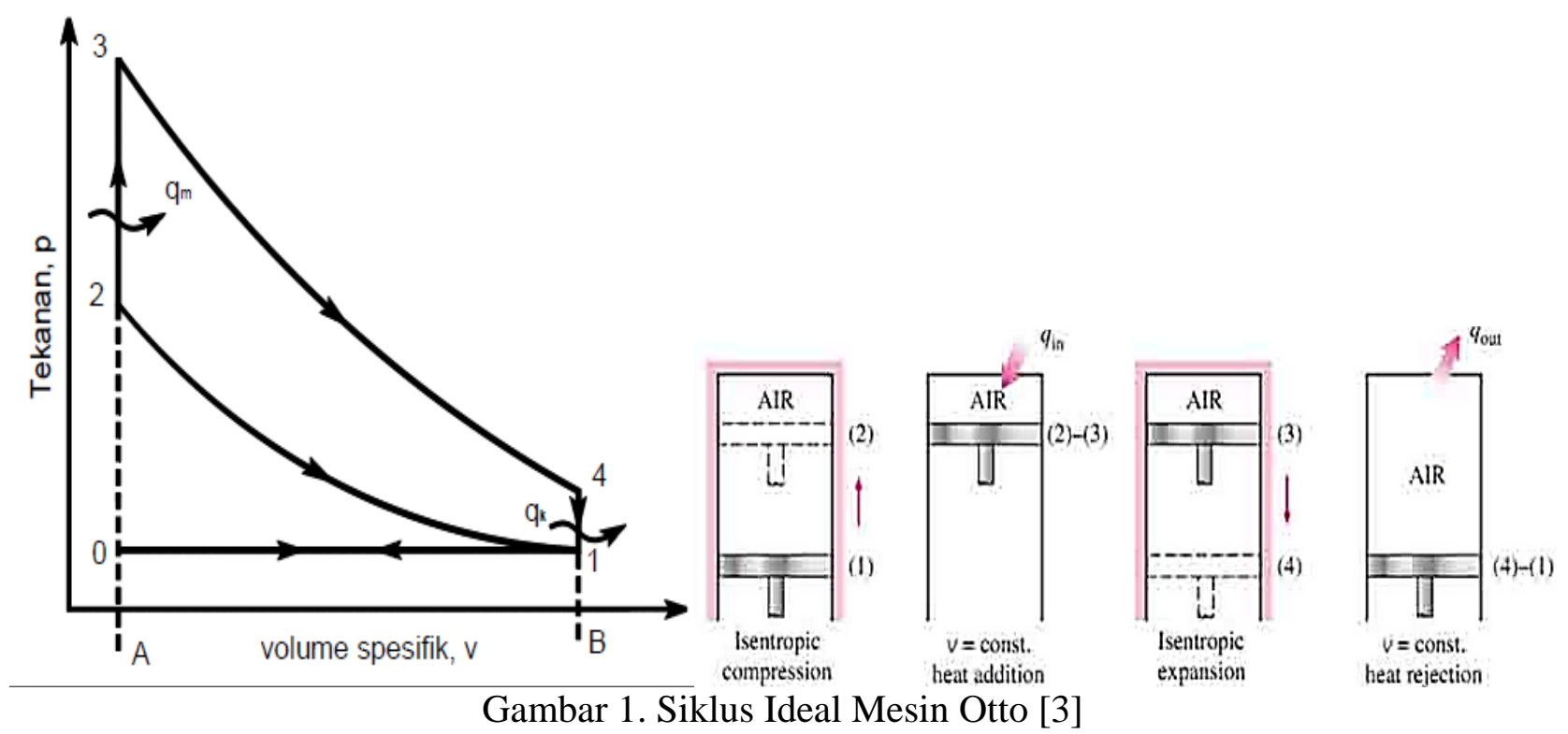


Adapun urutan prosesnya adalah sebagai berikut :

- Langkah isap (0-1) merupakan proses tekanan konstan.

- Langkah kompresi (1-2) merupakan proses adiabatik.

- Proses pembakaran volume konstan(2-3) dianggap sebagai proses pemasukan kalor pada volume kostan.

- Langkah kerja (3-4) merupakan proses adiabatik proses pembuangan kalor

- Proses pelepasan kalor (4-1) dianggap sebagai proses pengeluaran kalor pada volume konstan .

- Langkah buang (1-0) merupakan proses tekanan konstan, gas pembakaran dibuang lewat katup buang.

Pada siklus aktual pada mesin otto fluida kerja sesuai dengan kejadian secara aktualnya, yaitu campuran bahan bakar dan udara. Pada siklus ini kalor merupakan hasil dari proses pembakaran. Untuk langkah hisap tekanan lebih rendah dibanding dengan langkah buang. Proses kompresi dan ekspansi tidak pada kondisi adiabatis karena pada proses ini terdapat kerugian panas. Proses pembakaran dari penyalaan busi sampai akhir pembakaran. Untuk lebih jelas bisa dilihat diagram p-v di bawah ini.

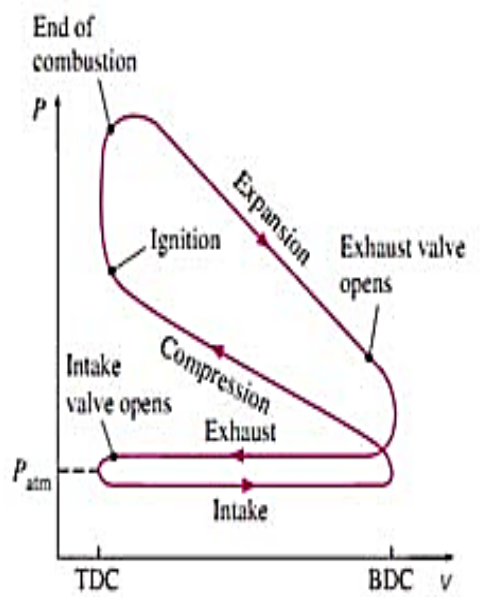

Gambar 2. Siklus Aktual Mesin Otto [3]

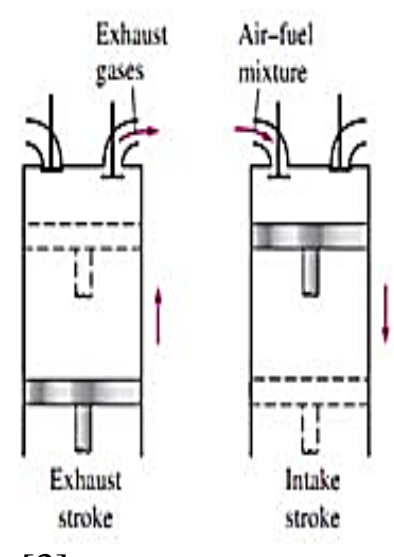

\section{METODE PENELITIAN}

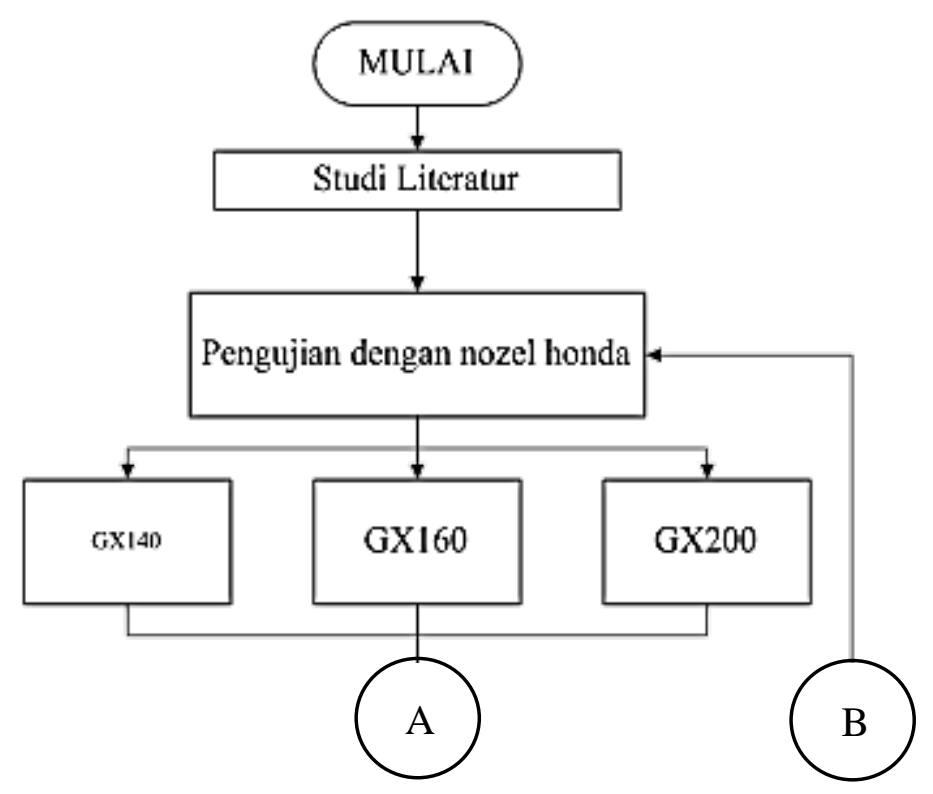

Gambar 3. Diagram alir penelitian. 
Lanjutan Gambar 3. Diagram alir penelitian.

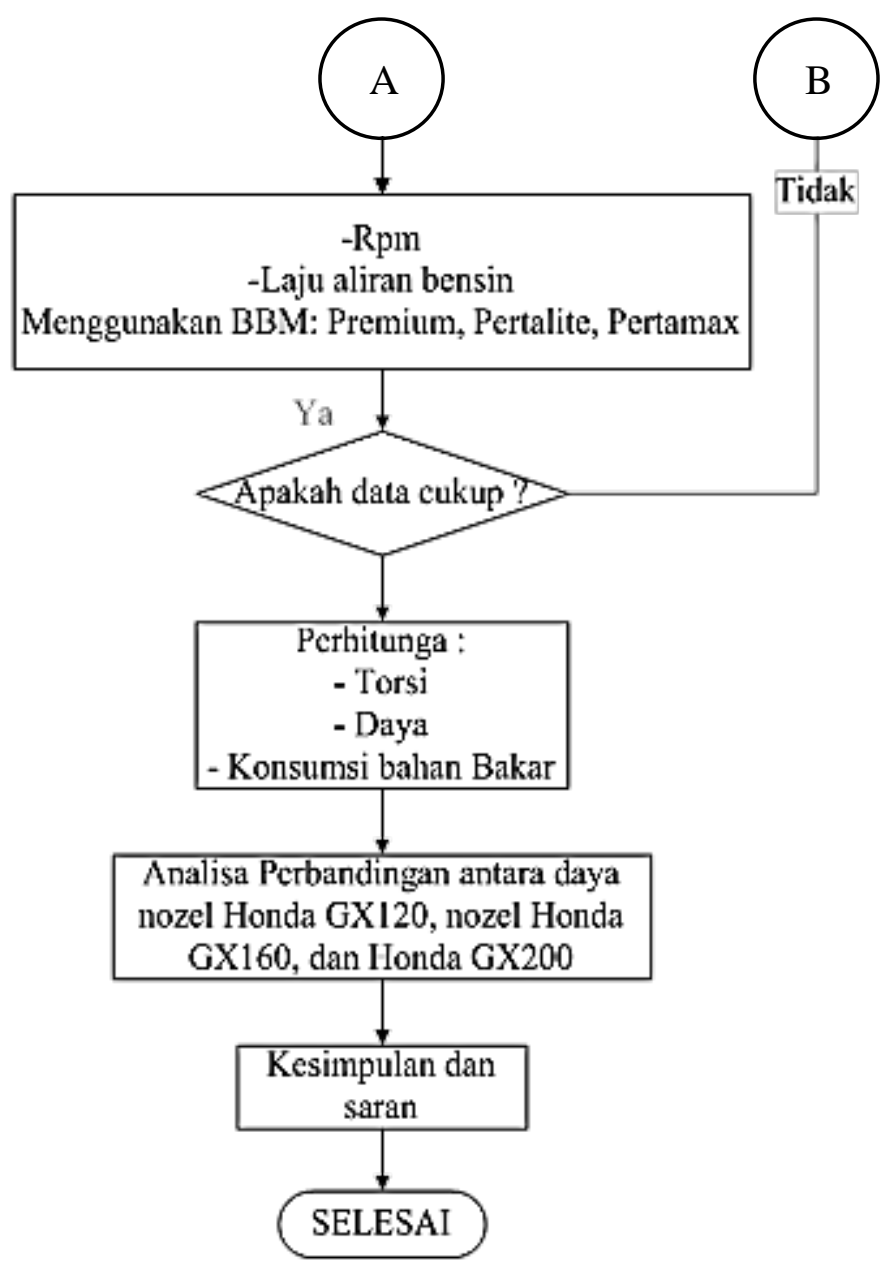

Penelitian atau eksperimen ini, dilakukan di Laboratorium Prestasi Mesin Jurusan Teknik Mesin Universitas Tarumanagara. Dalam penelitian ini alat dan bahan yang digunakan adalah: bahan yang di gunakan adalah karburator dan air. Alat yang digunakan adalah mesin motor bakar 4 langkah dengan 1 silinder. Dimana pada mesin motor bakar ini memiliki beberapa komponen yaitu: labu ukur, tangki bensin, forcemeter, tachometer, dan termokopel, busi, stopwatch.

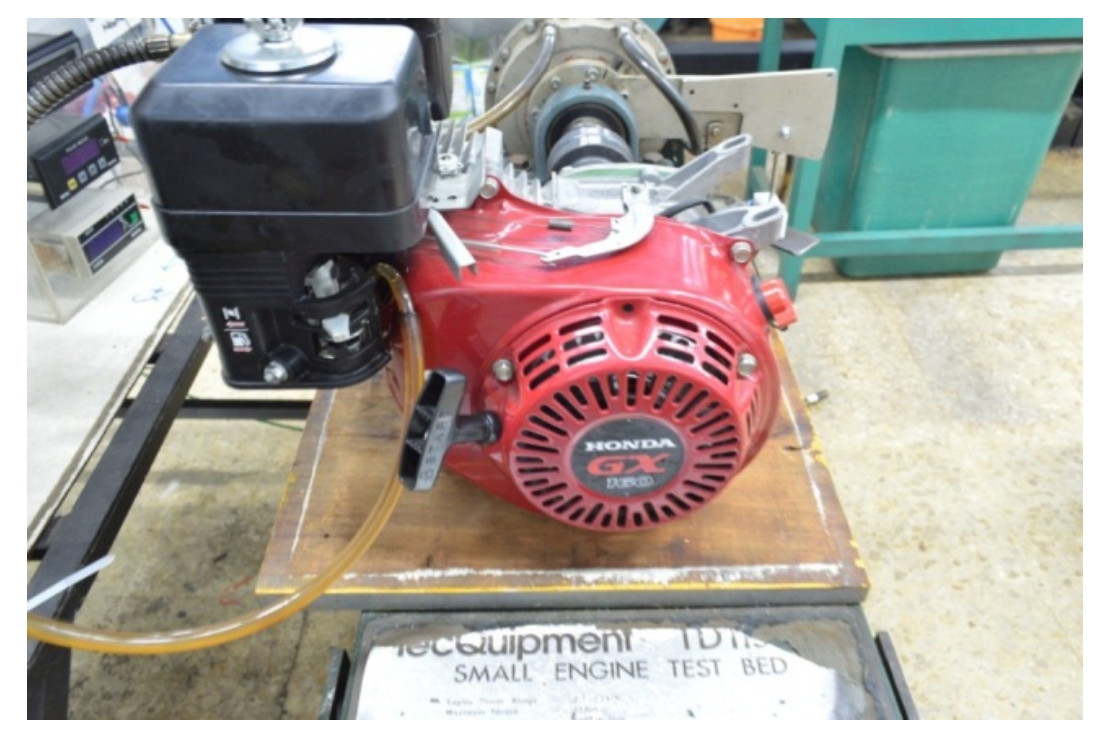

Gambar 4. Mesin Motor Bakar 


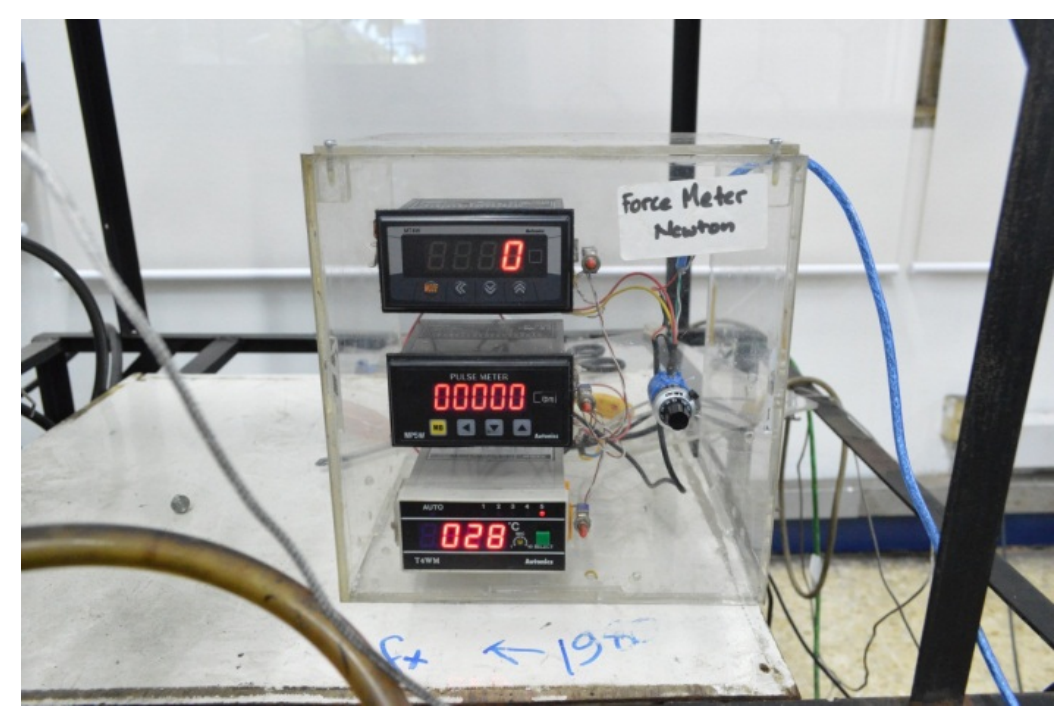

Gambar 5. Forcemeter, Tachometer dan Termokopel

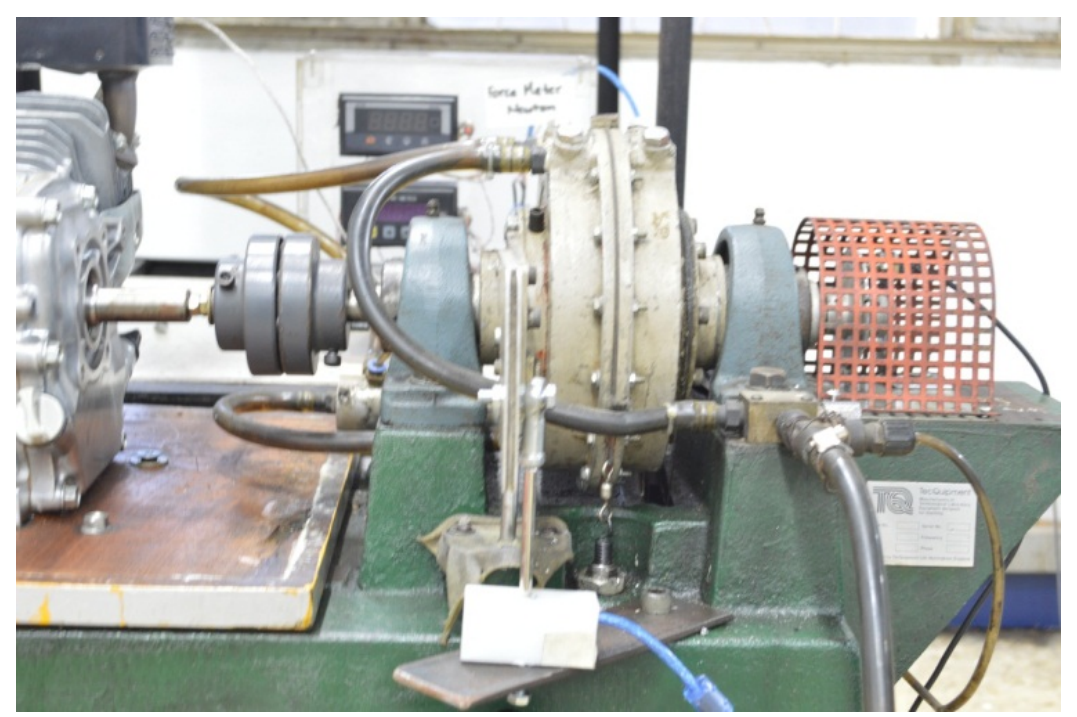

Gambar 6. Hydraulic Dynamometer

Langkah-langkah dalam melakukan eksperimental dengan mesin motor bakar dengan mainjet nosel yang berbeda adalah :

1. Mengisi bensin pada tangki bensin

2. Membuka keran nomer 1 untuk mengisi labu ukur lalu buka kembali keran nomer 2 untuk mengalirkan bensin menuju ke karburator atur bensin hingga berposisi penuh pada labu ukur yang berukuran $8 \mathrm{ml}$.

3. Pemasangan karburator yang suda siap dipakai dan busi yang baru. Dengan menggunakan kunci ring 10 dan kunci busi.

4. Menyalurkan semua termokopel, tachometer, forcemeter.

5. Menyalurkan air dan buka katub pada pornybrake sedikit demi sedikit dengan pembebanan yang kita suda atur.

6. Menyalurkan mesin dengan posisi on dan tarik engkol pada mesin.

7. Setelah menyala atur bukaan gas menuju rpm yang kita suda sepakati yaitu: 1300, 1700, 2100, 2500, 2900, 3400, 3800.

8. Ambil data laju bahan bakar, gaya, dan suhu pada masing-masing rpm tersebut.

9. Lalu perlahan turunkan putaran mesinnya lalu matikan.

10. Lakukan langkah nomer 2 sampai dengan 8 dengan 2 jenis karburator yang berbeda. 

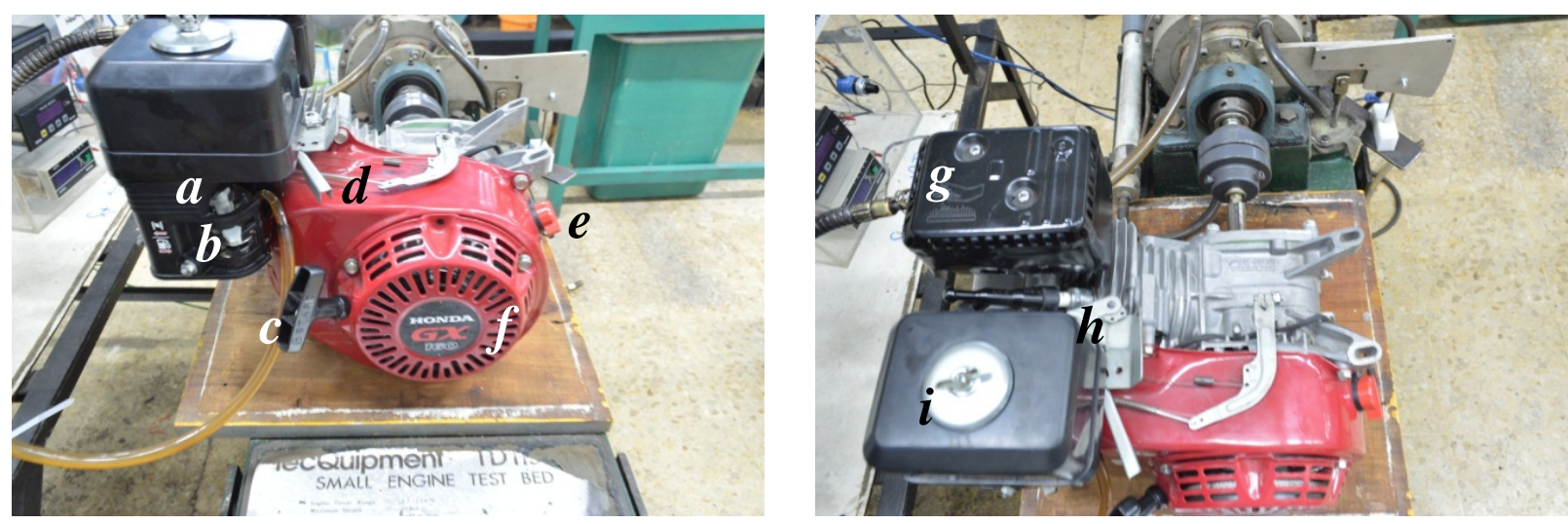

Gambar 7. Komponen pada Mesin Utama
a. Choke Lever
f. Recoil Starter
b. Fuel Valve
g. Muffler
c. Starter Grip
h. Spark Plug
d. Throttle Lever
i. Air Cleaner
e. Engine Switch

HASIL DAN PEMBAHASAN

Analisis Putaran VS Torsi.

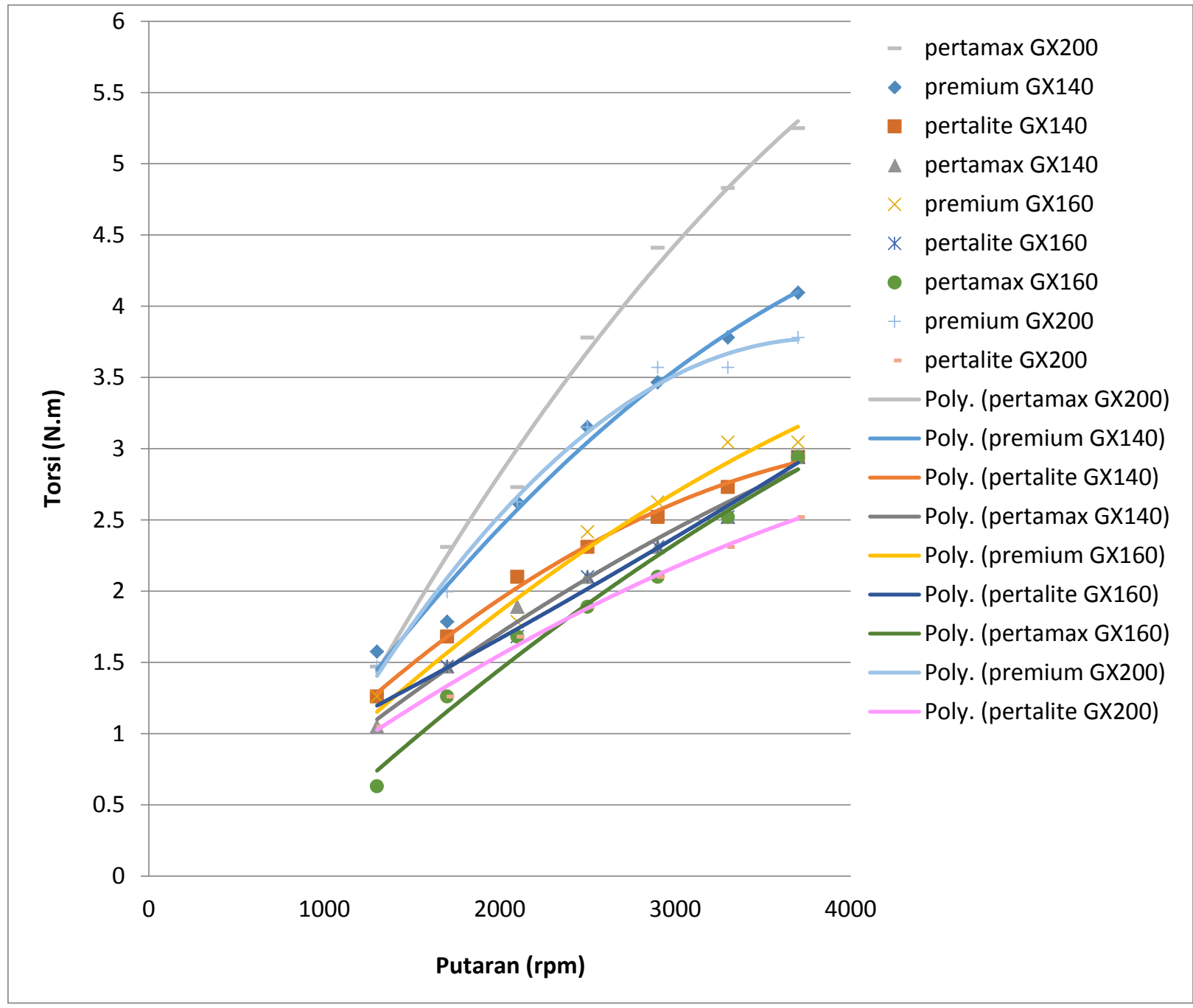

Gambar 8. Putaran VS Torsi 
Pada Gambar 8 diketahui bahwa torsi yang dihasilkan oleh nosel GX200 pada putara 3700 rpm menunjukan bahwa bahan bakar pertama lebih baik dari bahan bakar premium dan bahan bakar pertalite. Torsi terendah didapatkan pada nosel GX160 menggunakan bahan bakar Pertalite, karna kurang stabilnya pada putaran awal di 1300 rpm.

Hasil kali antara gaya dan lengan gaya ini dikenal dengan julukan torsi alias momen gaya. Jadi percepatan sudut benda sebanding alias berbanding lurus dengan torsi. Semakin besar torsi, semakin kecil percepatan sudut (percepatan sudut = perubahan kecepatan sudut).

\section{Analisis Putaran VS BHP.}

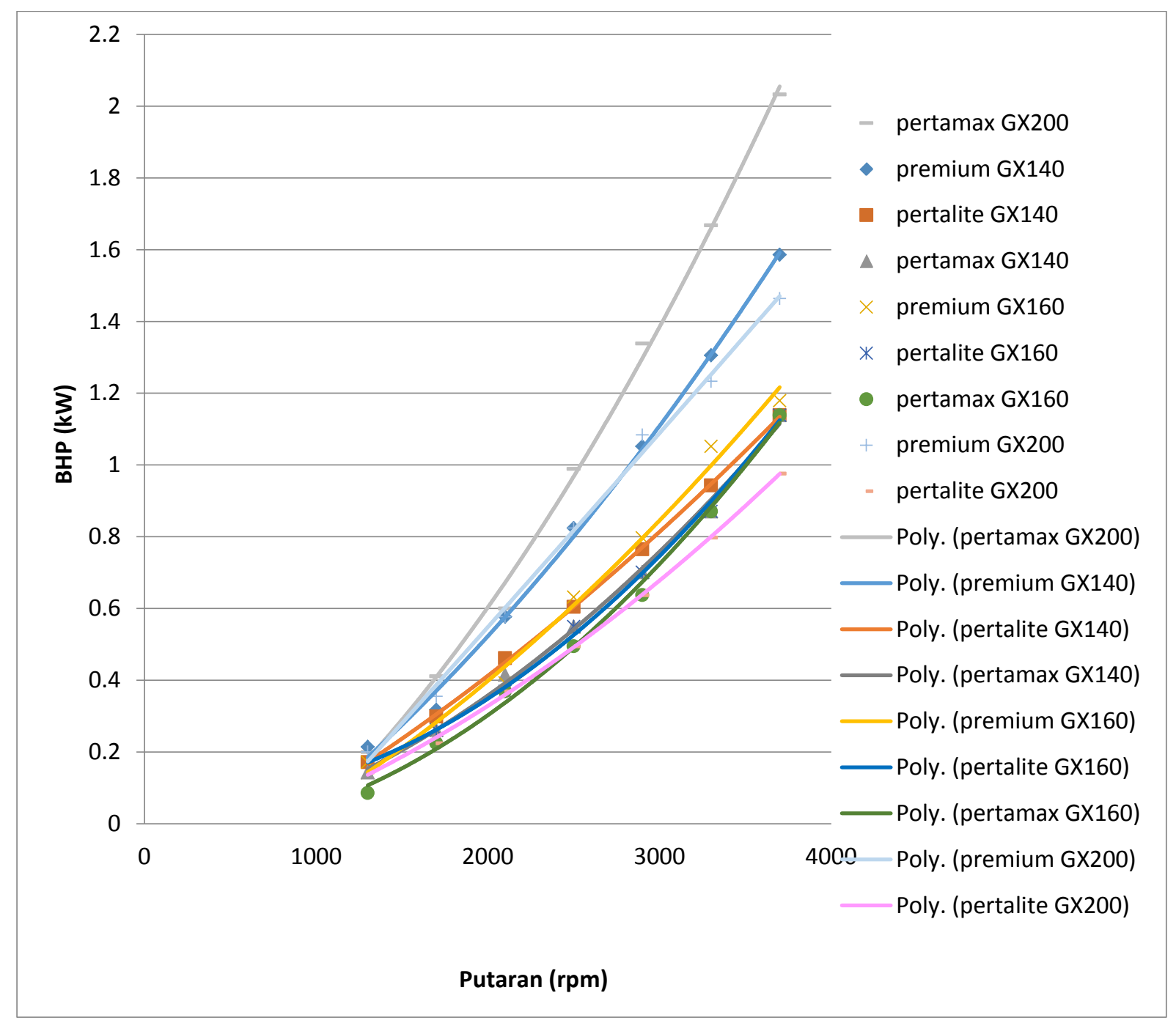

Gambar 9. Putaran VS BHP.

Pada Gambar 9 dipercobaan ini dapat diketahui bahwa daya tertinggi pada putaran mesin 3700 rpm oleh nosel GX200 menunjukan bahwa bahan bakar pertama lebih baik dari bahan bakar premium dan bahan bakar pertalie. Daya terendah didapatakan oleh nosel GX160 menggunkan bahan bakar pertalite.

Secara umum daya berbanding lurus dengan luas piston sedang torsi berbanding lurus dengan volume langkah. Parameter tersebut relatif penting digunakan pada mesin yang berkemampuan kerja dengan variasi kecepatan operasi dan tingkat pembebanan .Daya maksimum didefinisikan sebagai kemampuan maksimum yang bisa dihasilkan oleh suatu mesin. Adapun torsi poros pada kecepatan tertentu mengindikasikan kemampuan untuk memperoleh aliran udara dan 
juga bahan bakar yang tinggi ke dalam mesin pada kecepatan tersebut. Sementara suatu mesin dioperasikan pada waktu yang cukup lama, maka konsumsi bahan bakar serta efisiensi mesinnya menjadi hal yang sangat penting.[1]

\section{Analisis Putaran VS BSFC.}

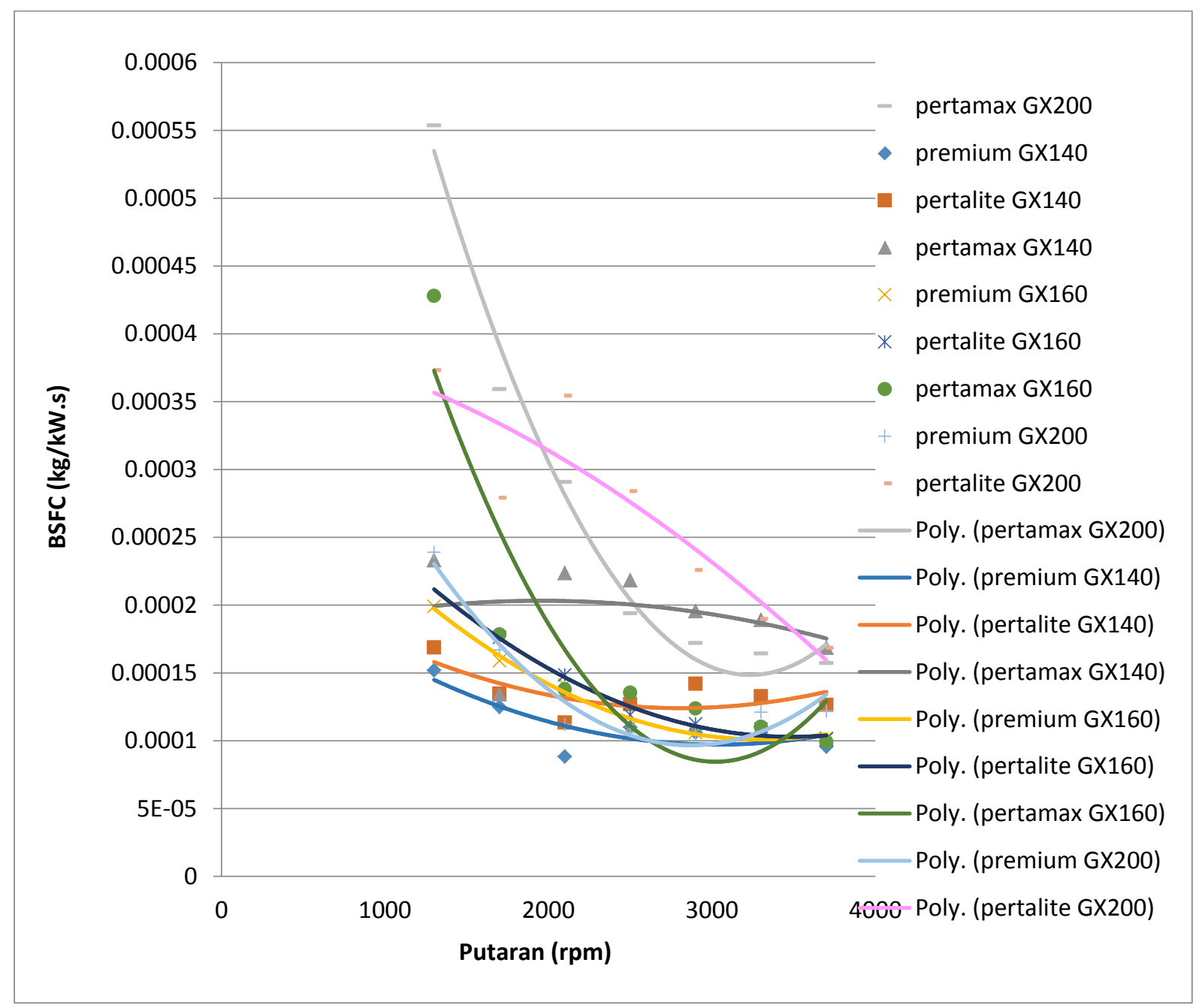

Gambar 10. Putaran vs BSFC.

Pada Gambar 10 percobaan ini dapat diketahui bahwa laju bahan bakar spesifik terendah pada nosel GX140 pada putaran 3700 rpm dengan mengunakan bahan bakar premium dibanding menggunkan bahan bakar pertalite, pertamax dan nosel GX160, nosel GX200.

Reaksi pembakaran adalah reaksi kimia bahan bakar dan oksigen yang diperoleh dari udara yang akan menghasilkan panas dan gas sisa pembakaran yang berlangsung dalam waktu yang sangat cepat. Reaksi pembakaran tersebut akan menghasilkan produk hasil pembakaran yang komposisinya tergantung dari kualitas pembakaran yang terjadi [5].

Dari grafik yang telah dibuat. Maka mendapatkan hasil pada putaran $1300 \mathrm{rpm}$ yang paling rendah efisiensi termalnya adalah nosel GX200 dan yang paling baik efisiensinya ialah GX140. Menurut hasil dari percobaan ini menunjukan efisiensi termal tertinggi adalah nosel GX140 dan paling rendah ialah GX200. Nilai dari efisiensi pada putaran $3700 \mathrm{rpm}$ dengan efisiensi tertinggi yaitu $23,76 \%$ dan nilai efisiensi termal pada saat $1300 \mathrm{rpm}$ yaitu 15\%.Sehingga pada performa dan dari akibat penggantian diameter nosel maka berdampak baik juga pada efisiensi termal ini. Tren yang cukup positif di hasilkan oleh nosel pengganti yaitu nosel GX140 dan nosel GX200. Dapat 
dipastikan bahwa nosel GX140 dinyatakan lebih baik di bandingkan dengan nosel GX160 yaitu nosel aslinya.

Analisis Putaran VS Efisiensi Termal.

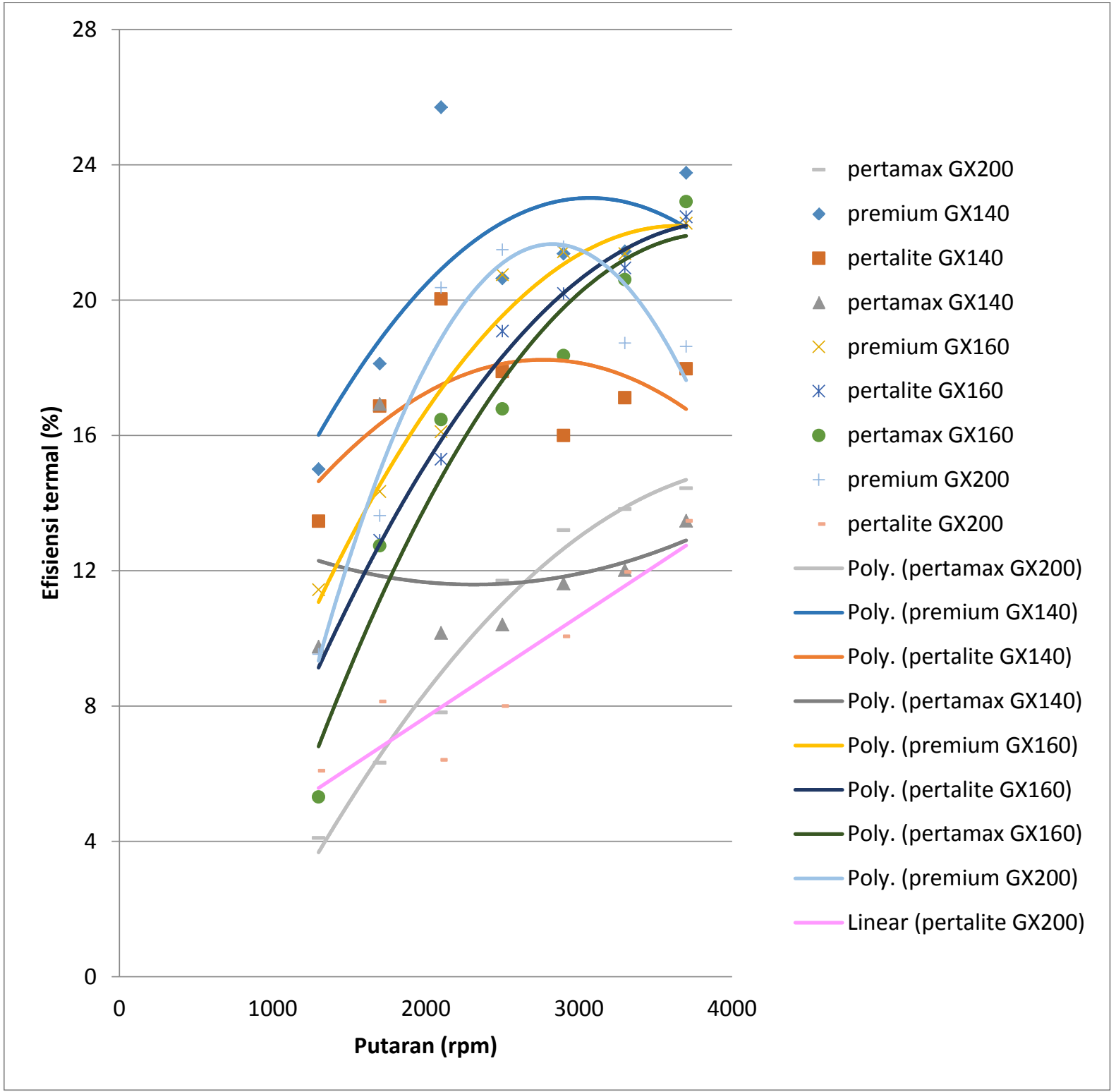

Gambar 11. Putaran vs Efisiensi Termal.

Efisiensi termal menyatakan perbandingan antara daya yang dihasilkan terhadap jumlah energi bahan bakar yang diperlukan untuk jangka waktu tertentu. Konsep efisiensi menjelaskan bahwa perbandingan antar energi berguna dengan energi yang masuk secara alamiah tidak pernah mencapai 100\%. [1]

\section{KESIMPULAN}

1. Dipengujian dengan mesin motor bakar yang menggunakan variasi diameter nosel ini, didapatkan bahwa penggunaan bahan bakar premium lebih baik pada nosel GX140 dibanding nosel GX160 dan nosel GX200. Bahan bakar pertalite menunjukan perfoma lebih baik pada nosel GX140 dan nosel GX160, dan bahan bakar pertamax menunjukan perfoma lebih baik pada nosel GX200. 
2. menggunakan bahan bakar premium dinosel GX140 mendapatkan torsi terbesar dengan nilai 4,09 Nm ketika di posisi 3700 rpm. Bahan bakar pertalite dinosel GX140 dan nosel GX160 mendapatkan torsi terbesar dengan nilai 2,94 Nm pada putaran mesin $3700 \mathrm{rpm}$. Sedangkan bahan bakar pertamax dinosel GX200 menghasilkan torsi terbesar dengan nilai 5,25 Nm pada putaran mesin $3700 \mathrm{rpm}$.

3. Penggunaan nosel GX200 untuk ke tiga bahan bakar premium, pertalite dan pertamax dinilai dari segi efisiensi kurang baik karena laju bahan bakar yang sangat tinggi.

4. Dari segi torsi, Daya, Laju bahan bakar dan efisiensi termal untuk bahan bakar premium yang terbaik ialah nosel GX140, dan bahan bakar pertalite yang terbaik ialah pada nosel GX140 dan nosel GX160. Sedangkan bahan bakar pertamax untuk torsi dan daya yang terbaik ialah pada nosel GX200, tetapi untuk laju bahan bakar dan efisiensi termal dinosel GX160.

\section{SARAN}

Adapun saran yang dapat saya berikan merupaka perbedaan diameter nosel dan perbedaan bahan bakar yang membuat unjuk kerja mesin motor bakar menjadi lebih baik. Pada penelitian ini dari tiga nosel yaitu nosel GX140, GX160 dan nosel GX200, lebih baik menggunakan nosel GX140 pada bahan bakar premium. Jika menginginkan laju bahan bakar yang rendah dan efisiensi yang tinggi menggunakan nosel GX140 dengan bahan bakar premium, tetapi jika menginginkan torsi dan daya yang besar menggunakan nosel GX200 dengan bahan bakar pertamax. Disebabkan butiran kecil yang memudahan proses pembakaran yang menjadi lebih baik. Perlunya pencobaan atau pengujian terhadap mesin tersebut terlebih dahulu karena tidak semua mesin berkarakteristik sama maka dari itu perlunya menguji diameter lebih besar atau diameter lebih kecil guna untuk mengetahui yang mana yang lebih baik terhadap performa mesin motor bakar tersebut. Perhitungan nilai LHV (Lower Heating Value) sesuaikan dengan karateristik cubic centimeter nya.

\section{DAFTAR PUSTAKA}

[1]. Ganesan. V. Internal Combustion Engine. McGraw-Hill. USA. 1996.

[2]. Jalius Jama, dkk. 2008. Teknik Sepeda Motor. Direktorat Pembinaan Sekolah Menengah Kejuruan: Jakarta.

[3]. Y. A. Cengel and M. A. Boles, Thermodynamics:An Engineering Approach, $5^{\text {th }}$ ed, McGrawHill. 2006.

[4]. AHM Buku Pedoman Reparasi Honda,2009

[5]. Keating, Eugene. L. Applied Combustion. USA: Marcel Dekker,Inc., 1993

[6]. Haryono,G. Uraian Praktis Mengenal Motor Bakar. Penerbit Aneka Ilmu, Semarang, 1997.

[7]. Arismunandar, Wiranto. Penggerak Mula Motor Bakar Torak, edisi kelima. Institut Teknologi Bandung, Bandung, 2002.

[8]. Sunyoto,dkk. 2008. Teknik Mesin Industri. Direktorat Pembinaan Sekolah Menengah Kejuruan: Jakarta.

[9]. V.L Malev. Internal Combustion Engine. Mc Graw - Hill Book Company, Singapore, 2008.

[10]. Arends, B. Motor Bensin. Jakarta, Erlangga, 1980. 